\title{
Bacterial protein meal in diets for growing pigs: effects on protein and energy metabolism
}

\author{
A. L. F. Hellwing ${ }^{1}$, A.-H. Tauson ${ }^{1,3 \dagger}{ }^{\dagger}$, N. P. Kjos $^{2}$ and A. Skrede ${ }^{2,3}$ \\ ${ }^{1}$ Department of Animal and Veterinary Basic Sciences, The Royal Veterinary and Agricultural University, Grønnegaardsvej 3, DK-1870 Frederiksberg C, \\ Denmark; ${ }^{2}$ Department of Animal and Aquacultural Sciences, Norwegian University of Life Sciences, PO Box 5003, N-1432 Ås, Norway \\ ${ }^{3}$ Aquaculture Protein Centre Centre of Excellence, PO Box 5003, N-1432 Ås, Norway
}

(Received 27 September 2005; Accepted 12 September 2006)

\begin{abstract}
This experiment investigated the effects of increasing the dietary content of bacterial protein meal (BPM) on the protein and energy metabolism of pigs from weaning to a live weight of $80 \mathrm{~kg}$. Four litters with four castrated male pigs in each litter were used. The litters were divided into two blocks according to age. One pig from each litter was fed one of the four experimental diets. Soya-bean meal was replaced with BPM on the basis of digestible protein, and the BPM contents in the four diets were $0 \%$ (BP0), 5\% (BP5), 10\% (BP10) and 15\% (BP15), corresponding to $0 \%, 17 \%, 35 \%$ and $52 \%$ of the digestible nitrogen (N), respectively. Four balance periods were performed, at the start of which the pigs weighed $9.5 \mathrm{~kg}, 20.7 \mathrm{~kg}, 45.3 \mathrm{~kg}$ and $77.2 \mathrm{~kg}$, respectively. Once during each balance period, 22-h respiration experiments were performed using indirect calorimetry. Daily weight gain, feed intake and feed conversion rate were the same for all diets. The apparent digestibility of $N$ was lower on diet $B P 10$ than on $B P O(P=0.002)$, whereas the apparent digestibility of energy was similar on all diets. The retention of nitrogen did not differ between diets and was $1.50,1.53,1.33$ and $1.46 \mathrm{~g} \mathrm{~N}$ per kg ${ }^{0.75}$ per day on BPO, BP5, BP10 and BP15, respectively. Neither metabolisable energy intake nor heat production were affected by inclusion level of BPM. Retention of energy was 620 (BP0), 696 (BP5), 613 (BP10) and $664 \mathrm{~kJ} / \mathrm{kg}^{0.75}$ per day (BP15), the differences among diets being non-significant. The N-free respiratory quotient was similar on all diets. It was concluded that the overall protein and energy metabolism in growing pigs were not affected when up to $50 \%$ of dietary $N$ was derived from BPM.
\end{abstract}

Keywords: bacterial protein meal, energy metabolism, pigs, protein metabolism

\section{Introduction}

The global demand for high-quality protein feedstuffs for use in animal nutrition is increasing: fish for the production of fish meal is a limited resource, meat and bone meal and other animal by-products are banned in many countries owing to bovine spongiform encephalitis, and important vegetable protein sources are increasingly genetically modified and thus considered unsuitable for diets of food producing animals in many countries. Therefore, alternative protein sources must continuously be evaluated and, if proved suitable, be included in the diets of farm and companion animals. The prerequisites for a protein feedstuff to be considered of high nutritional quality include good palatability, high biological value, harmlessness and being beneficial to product quality. Evaluation studies conducted

\footnotetext{
${ }^{\dagger}$ E-mail: aht@kvl.dk
}

with fast-growing animals such as pigs and chickens may form a suitable basis for conclusions on the usefulness of such alternative protein feedstuffs.

Bacterial protein meal (BPM) produced by the continuous aerobic fermentation of natural gas ( $99 \%$ methane) as the energy and carbon source and ammonium as the nitrogen source is a new interesting potential protein source (Skrede et al., 1998). The bacterial biomass comprises Methylococcus capsulatus (Bath; >90\%), Ralstonia sp., Brevibacillus agri and Aneurinibacillus sp. After fermentation the biomass is spray dried and heat-treated to obtain a dry and storagestable reddish/brown product with a dry matter (DM) content of approximately $96 \%$. The crude protein (CP), fat and ash contents are approximately $70 \%, 10 \%$ and $7 \%$, respectively (Skrede et al., 1998). Nitrogen (N) from the purine and pyrimidine bases in RNA and DNA makes up approximately $12 \%$ of the $N$ in BPM. This level is low compared with that of many other single-cell proteins of bacterial origin (Braude 
et al., 1977; Tiemeyer et al., 1981; Rumsey et al., 1991; Kiessling and Askbrandt, 1993) but considerably higher than that of fish meal (Greife, 1984), wheat, barley, maize and soya beans (Herbel and Montag, 1987; Imafidon and Sosulski, 1990; Lassek and Montag, 1990).

In pig diets, BPM may be used to replace soya-bean meal (SBM). Compared with that of SBM, the amino acid composition of BPM mainly differs in having a slightly higher content of S-containing amino acids (with a somewhat lower cystine but a higher methionine content). For other essential amino acids, only minor differences between SBM and BPM have been reported (Øverland et al., 2001).

Growth trials suggest that BPM may be a promising alternative protein source, but some varying and contradictory results have been observed (Øverland et al., 2001 and 2004; Skrede et al., 2003; Storebakken et al., 2004). Dietary BPM providing up to one-third of the $N$ intake was found to sustain animal performance and health in slaughter chickens (Skrede et al., 2003) and blue foxes (Skrede and Ahlstrøm, 2002). When BPM made up approximately $50 \%$ of dietary $\mathrm{N}$, no adverse effects were reported for growing-finishing pigs (Øverland et al., 2001) or Atlantic salmon (Storebakken et al., 2004). In piglets, however, when 40 to $50 \%$ of dietary $\mathrm{N}$ originated from BPM, reduced performance during the piglet period was noted in some experiments (Øverland et al., 2001 and 2004).

A complete feedstuff evaluation cannot be based solely on performance data (Øverland et al., 2001 and 2004) but also needs to consider effects on protein and fat deposition. A high-quality protein source must sustain high $\mathrm{N}$ retention and not cause elevated heat production (HE). Effects of including BPM in the diet on protein and energy deposition are still limited to studies in chicken and mink, which showed that retained nitrogen (RN) remained unaffected when BPM made up 20 to $60 \%$ of digestible $N$ in the mink diet (Hellwing et al., 2005) or 6.5 to $20 \%$ in the chicken diet (Hellwing et al., 2006). The heat production in mink (Hellwing et al., 2005) as well as in chickens (Hellwing et al., 2006) was the same on the control diet and the diets with BPM.

Previous production experiments with BPM in diets for monogastric species (Øverland et al., 2001 and 2004; Skrede and Ahlstrøm, 2002; Skrede et al., 2003; Storebakken et al., 2004), and $\mathrm{N}$ and energy metabolism studies in mink and chickens (Hellwing et al., 2005 and 2006), have given somewhat varying and contradictory results. Therefore, the objective of the present study was, by means of balance and respiration experiments, to reveal effects of replacement of SBM by BPM on $\mathrm{N}$ and energy metabolism in balanced diets for growing-finishing pigs. Our hypothesis was that protein and energy retention would be negatively affected by an increasing proportion of dietary $\mathrm{N}$ from RNA and DNA in the diets with increasing dietary supply of BPM.

\section{Material and methods}

Animals and experimental design

The experiment was conducted as a block experiment with four dietary treatments and the same sixteen pigs were measured four times from weaning until $80 \mathrm{~kg}$. Two blocks ( $A$ and $B$ ) were used and the blocks were measured with one-week in-between. In each block eight recently weaned barrows [(Landrace $\times$ Yorkshire $) \times($ Hampshire $\times$ Duroc $)]$ from two litters were used. One pig from each litter was allocated to one of the four dietary treatments. At arrival the barrows in block $A$ weighed $8.2 \pm 0.6 \mathrm{~kg}$ (mean \pm s.d.) and the barrows in block $B 9.8 \pm 0.9 \mathrm{~kg}$. Four spare pigs having the same age as the barrows in block $A$ were fed the control diet.

The experimental diets were fed from day one after arrival. At 9 days after arrival the pigs were placed in metabolism cages and the first 4-day balance period started at 12 days after arrival. Another three balance periods were conducted at 40, 68 and 96 days after arrival. Once during each balance period the barrows were subjected to a $22-h$ respiration experiment by means of indirect calorimetry in an open-air circulation system (Chwalibog et al., 2004).

\section{Diets}

The batch of BPM (Bioprotein $\AA$, Norferm AS, Stavanger, Norway) used in this experiment was pelleted with inclusion of approximately $1 \%$ soya oil after spray-drying in order to minimise dusting. All ingredients were then mixed and the diets pelleted. In order to use diets that were in agreement with the actual nutritional requirement of the pigs, diets designed for weaned piglets were used in periods 1 and 2, and diets designed for growing-finishing pigs were used in periods 3 and 4 . The BPM content of the starter and growing finishing diets remained the same, but the $\mathrm{N}$ and energy contents were somewhat reduced in the growing-finishing diet in order to comply with the animals' decreasing protein requirements. The starter diet was used from arrival until the end of balance period 2, and the growing-finishing diet was used during the rest of the experiment. One of the experimental diets served as the control diet and contained no BPM (BP0), while the remaining diets contained $5 \%$ BPM (BP5), 10\% BPM (BP10) and 15\% BPM (BP15) (Table 1). The BPM replaced SBM on a digestible protein basis, providing $0 / 0,17 / 17,33 / 35$ and $49 / 52 \%$ of $N$ in the starter and growing-finishing diets, respectively. The contents of digestible protein were calculated by using digestibility values indicated by Skrede et al. (1998) for BPM, and table values for the other feed ingredients (Norwegian Feed Table, 2002). The diets were formulated to meet or exceed the requirements for essential amino acids and all other nutrients established by the National Research Council (NRC, 1998). The diets were produced by the Centre for Feed Technology (Ås, Norway) and pelleted using a 3-mm die on a Münch pellet press (Münch-Edelstahl GmbH, Hilden, Germany). For a more detailed description of the diet formulation, see Øverland et al. (2004). All diets were 
Bacterial protein meal in diets for growing pigs

Table 1 Composition and chemical content of the diets used in balance and respiration experiments with pigs

\begin{tabular}{|c|c|c|c|c|c|c|c|c|}
\hline & \multicolumn{4}{|c|}{ Starter diet } & \multicolumn{4}{|c|}{ Growing-finishing diet } \\
\hline & BPO & BP5 & BP10 & BP15 & BPO & BP5 & BP10 & BP15 \\
\hline Barley (g/kg) & 226 & 246 & 250 & 270 & 487 & 518 & 541 & 563 \\
\hline Wheat $(\mathrm{g} / \mathrm{kg})$ & 480 & 480 & 500 & 497 & 250 & 250 & 250 & 250 \\
\hline Bacterial protein meal (BPM) (g/kg) & 0 & 52 & 101 & 153 & 0 & 50 & 100 & 150 \\
\hline Soya-bean meal ( $45 \%$ crude protein) $(\mathrm{g} / \mathrm{kg})$ & 210 & 140 & 68 & 0 & 224 & 146 & 72 & 0 \\
\hline Soya oil $(g / k g)$ & 40 & 40 & 40 & 40 & 6.0 & 3.6 & 5.0 & 5.0 \\
\hline Limestone $(\mathrm{g} / \mathrm{kg})$ & 15.8 & 16.2 & 16.6 & 16.9 & 14.2 & 14.2 & 14.2 & 14.2 \\
\hline Monocalcium phosphate $(\mathrm{g} / \mathrm{kg})$ & 15.4 & 14.8 & 14.4 & 13.9 & 11.7 & 11.7 & 11.8 & 11.8 \\
\hline Sodium chloride $(\mathrm{g} / \mathrm{kg})$ & 4.7 & 4.6 & 4.5 & 4.40 & 3.8 & 3.7 & 3.6 & 3.5 \\
\hline Iron fumarate $(\mathrm{g} / \mathrm{kg})$ & 0.33 & 0.33 & 0.33 & 0.33 & & & & \\
\hline Zinc oxide $(\mathrm{g} / \mathrm{kg})$ & 0.10 & 0.10 & 0.10 & 0.10 & & & & \\
\hline Pre-mix starter diet $^{\dagger}(\mathrm{g} / \mathrm{kg})$ & 3.03 & 3.03 & 3.03 & 3.03 & & & & \\
\hline Pre-mix growing-finishing $\operatorname{diet}^{\ddagger}(\mathrm{g} / \mathrm{kg})$ & & & & & 1.8 & 1.8 & 1.8 & 1.8 \\
\hline L-lysine $\mathrm{HCl}(98 \%)(\mathrm{g} / \mathrm{kg})$ & 3.4 & 2.5 & 1.8 & 0.7 & 0.65 & 0.64 & 0.51 & 0.34 \\
\hline DL-methionine $(\mathrm{g} / \mathrm{kg})$ & 0.30 & 0.0 & 0.0 & 0.0 & 0.54 & 0.32 & 0.06 & 0.0 \\
\hline L-threonine $(\mathrm{g} / \mathrm{kg})$ & 1.0 & 0.63 & 0.4 & 0.0 & 0.60 & 0.37 & 0.09 & 0.0 \\
\hline L-tryptophan (g/kg) & 0.15 & 0.21 & 0.3 & 0.35 & & & & \\
\hline \multicolumn{9}{|l|}{ Chemical composition } \\
\hline Dry matter $(\mathrm{g} / \mathrm{kg})$ & 919 & 917 & 918 & 916 & 881 & 886 & 892 & 890 \\
\hline Ash $(g / k g)$ & 67.4 & 59.3 & 59.6 & 59.0 & 55.8 & 54.9 & 50.5 & 54.6 \\
\hline Crude protein $(\mathrm{N} \times 6.25)(\mathrm{g} / \mathrm{kg})$ & 198 & 198 & 200 & 206 & 191 & 197 & 189 & 190 \\
\hline Fat $(\mathrm{g} / \mathrm{kg})$ & 36.9 & 40.3 & 52.1 & 73.5 & 27 & 32 & 40 & 43 \\
\hline Gross energy (MJ/kg) & 17.5 & 17.4 & 17.5 & 17.8 & 16.0 & 16.3 & 16.7 & 16.6 \\
\hline Lysine $(\mathrm{g} / \mathrm{kg})$ & 10.7 & 10.2 & 9.8 & 8.6 & 9.9 & 10.0 & 9.1 & 8.2 \\
\hline Methionine $(\mathrm{g} / \mathrm{kg})$ & 2.8 & 2.9 & 3.4 & 3.8 & 3.0 & 3.6 & 3.5 & 3.7 \\
\hline Cystine $(\mathrm{g} / \mathrm{kg})$ & 3.1 & 3.0 & 2.8 & 2.5 & 3.2 & 2.9 & 2.6 & 2.4 \\
\hline Threonine $(\mathrm{g} / \mathrm{kg})$ & 7.0 & 6.9 & 7.1 & 6.8 & 7.1 & 7.4 & 6.8 & 6.6 \\
\hline Tryptophan (g/kg) & 2.5 & 2.7 & 2.9 & 3.2 & 2.6 & 2.9 & 3.0 & 3.2 \\
\hline \multicolumn{9}{|l|}{ Purine bases } \\
\hline Adenine (mg/kg) & 392 & 899 & 1272 & 1905 & 446 & 1027 & 1345 & 1743 \\
\hline Guanine (mg/kg) & 347 & 770 & 1148 & 1617 & 370 & 876 & 1155 & 1518 \\
\hline \multicolumn{9}{|l|}{ Pyrimidine bases } \\
\hline Cytosine (mg/kg) & 506 & 939 & 1328 & 1794 & 522 & 1083 & 1428 & 1783 \\
\hline Uracil (mg/kg) & 722 & 1031 & 1177 & 1541 & 790 & 1267 & 1508 & 1732 \\
\hline Thymine $(\mathrm{mg} / \mathrm{kg})$ & 139 & 208 & 265 & 347 & 126 & 240 & 252 & 284 \\
\hline $\mathrm{N}$ from purine and pyrimidine bases ( $\%$ of all nitrogen) & 2.5 & 5.0 & 7.1 & 9.6 & 2.7 & 5.6 & 7.7 & 9.7 \\
\hline
\end{tabular}

${ }^{\dagger}$ Vitamins and trace elements included to provide the following per kg of feed: $140 \mathrm{mg} \mathrm{Zn;} 201 \mathrm{mg}$ Fe; $80 \mathrm{mg} \mathrm{Mn;} 20 \mathrm{mg} \mathrm{Cu} ; 10 \mathrm{mg} \mathrm{I}, 0.4 \mathrm{mg} \mathrm{Se} ; 300 \mu \mathrm{g}$ retinol; $34.4 \mu \mathrm{g}$ cholecalciferol; $137.5 \mathrm{mg}$ D- $\alpha$-tocopheryl acetate; $6.9 \mathrm{mg}$ riboflavin; $22.9 \mathrm{mg}$ D-pantothenic acid; $27.5 \mu \mathrm{g}$ cyanocobalamin.

${ }^{\ddagger}$ Vitamins and trace elements included to provide the following amounts per $\mathrm{kg}$ of feed: $105 \mathrm{mg} \mathrm{Zn;} 75 \mathrm{mg} \mathrm{Fe} ; 60 \mathrm{mg} \mathrm{Mn} ; 15 \mathrm{mg} \mathrm{Cu} ; 7.44 \mathrm{mg} \mathrm{l} ; 0.3 \mathrm{mg} \mathrm{Se}$; $2520 \mu \mathrm{g}$ retinol, $17.5 \mu \mathrm{g}$ cholecalciferol; $115.9 \mathrm{mg}$ D- $\alpha$-tocopheryl acetate; $5 \mathrm{mg}$ riboflavin; $15 \mathrm{mg}$ D-panthothenic acid; $20 \mathrm{mg}$ cyanocobalamin.

analysed for DM, ash, N, fat, energy, amino acids, purine and pyrimidine bases (Table 1).

\section{Housing and feeding}

The pigs were housed individually for the duration of the experiment. For the first 9 days after arrival and between balance periods they were housed in pens with concrete floors covered with wood shavings. During the balance periods the pigs were housed in metabolic cages of stainless steel, $(1.65 \mathrm{~m} \times 0.75 \mathrm{~m}$ with a slatted floor of round stainless steel bars). When kept in the balance cages and the pens, but not in the respiration chambers, the pigs had visual contact. The light schedule was $12 \mathrm{~h}$ light and $12 \mathrm{~h}$ dark. Between balance periods the pigs were fed twice daily (0830 and $1530 \mathrm{~h}$ ) but during balance periods they were fed once daily between 1130 and $1200 \mathrm{~h}$. The feed supply was regulated on a daily basis to a level where pigs had a minimum of feed residues, i.e. were fed as close to ad libitum as possible. Between balance periods, water was provided ad libitum from drinking nipples. During the balance periods, water (twice the weight of the feed) was mixed into the diets. In addition, pigs were given drinking water in a trough. The temperature was kept at 20 to $22^{\circ} \mathrm{C}$ throughout the experimental period. All pigs were provided with a rubber mat in the front of the metabolism cages during the first and second balance periods.

\section{Experimental techniques}

Pigs were weighed at the start and end of each 4-days balance period. The collection procedures were performed 
between 0800 and $1200 \mathrm{~h}$ every day. Feed residues, faeces and urine were quantitatively collected from the individual pigs, weighed and frozen at $-18^{\circ} \mathrm{C}$. Urine was collected in $30 \mathrm{ml}$ of $5 \%$ sulphuric acid in periods 1 and 2 and in $50 \mathrm{ml}$ of $5 \%$ sulphuric acid in periods 3 and 4 . For 2 days in periods 2 and 4 when protein turn-over was estimated by means of the ${ }^{15} \mathrm{~N}$-glycine end-point technique the addition of acid was omitted. The results from the protein turn-over experiment will be reported elsewhere (Hellwing et al., 2007).

The inside surfaces of the metabolic cage, the mat and collection plate were washed with citric acid daily after completion of the collection procedures. After each balance period feed residues, faeces and urine were thawed and mixed to homogeneity. Samples for chemical analyses were taken and frozen at $-18^{\circ} \mathrm{C}$ for later analyses. Furthermore, samples of faeces were freeze-dried for analyses of ash, fat and energy. The citric acid rinse was thawed and centrifuged at $3000 \times \mathbf{g}$ for $10 \mathrm{~min}$ to separate the solid particles (assumed to be faeces residues) from the fluid (assumed mainly to contain $\mathrm{N}$ residues derived from urine). The sediment was weighed and freeze-dried. A sample of the supernatant was stored at $-18^{\circ} \mathrm{C}$.

The day when the pigs were subjected to the respiration experiment they were brought to the respiration unit between 0930 and $1030 \mathrm{~h}$. Each respiration experiment lasted $22 \mathrm{~h}$, starting at $1100 \mathrm{~h}$ and ending at $0900 \mathrm{~h}$ the following morning. The volume of each respiration chamber was $3500 \mathrm{I}$ and the chambers were constructed for animals with live weights of 5 to $200 \mathrm{~kg}$. For a detailed description of the calibration and measurement procedures, see Chwalibog et al. (2004).

\section{Analyses}

Samples of diets and freeze-dried faeces were ground and homogenised before analyses. Feed residues were analysed for DM, assuming that the composition of the DM was the same as in the DM of the feed. Wet faeces were analysed for DM and N and freeze-dried faeces for ash, fat and energy. Urine was analysed for $\mathrm{N}$. The supernatant of the citric acid rinse was analysed for N, and the DM content of the sediment was determined by freeze-drying.

DM was determined by evaporation at $105^{\circ} \mathrm{C}$ to constant weight. Ash was determined by incineration at $525^{\circ} \mathrm{C}$. N was determined by the micro-Kjeldahl technique using the Tecator-Kjeltec system 1030 (Tecator AB, Höganäs, Sweden). CP was calculated as $N \times 6.25$. Fat was determined by petroleum ether extraction in a Soxtec system after $\mathrm{HCl}$ hydrolysis. Gross energy was determined using an adiabatic bomb calorimeter (IKA Calorimeter system, IKA Gmbh and Co. KG, Staufen, Germany). The amino acids, except tryptophan, in the diets were determined according to the European Community (1998). Tryptophan was analysed according to the Bech-Andersen (1991) procedure. Adenine, guanine, thymine, uracil, and cytosine in the diets were determined by a HPLC method. A diet sample of $0.100 \mathrm{~g}$ was mixed with $2 \mathrm{ml}$ of $\mathrm{HClO}_{4}$ and heated for $1 \mathrm{~h}$ at $95^{\circ} \mathrm{C}$. The sample was chilled and mixed with $5 \mathrm{ml}$ borate buffer and $3 \mathrm{ml} 12.4 \mathrm{mmol} / \mathrm{KOH}$. A sample of $1 \mathrm{ml}$ was taken and centrifuged at 15000 r.p.m. for $10 \mathrm{~min}$. To the centrifuged sample $4 \mathrm{ml}$ borate buffer was added and micro-filtrated $(0.45 \mu \mathrm{m})$. The sample was injected into the column and eluents were detected by UV-absorbance at $254 \mathrm{~nm}$. Data were analysed against external standards using the HewlettPackard HP ChemStation Software (Møller-Hansen, personal communication).

\section{Calculations}

Urinary nitrogen (UN) was calculated as the sum of the $\mathrm{N}$ in the urine and the citric acid rinse. Faecal nitrogen (FN) was calculated as the $\mathrm{N}$ content of the faeces plus the $\mathrm{N}$ content of the sediment from citric acid rinse. It was assumed that the $\mathrm{N}$ content of the sediment was the same as that of the faeces. Energy in urine (UE) was calculated as $53.5 \mathrm{~kJ} / \mathrm{g} \times$ UN (Chwalibog et al., 2004). RN was calculated as ingested nitrogen (IN) minus UN and FN. Metabolisable energy (ME) was calculated by subtracting FE and UE from gross energy intake. Heat production (HE) was calculated according to Brouwer (1965) as $\mathrm{HE}, \mathrm{kJ}=$ $16.18 \times \mathrm{O}_{2}, \mathrm{~L}+5.02 \times \mathrm{CO}_{2}, \mathrm{~L}-5.99 \times \mathrm{UN}, \mathrm{g}-2.17 \times \mathrm{CH}_{4}$, L. The production of $\mathrm{CH}_{4}$ was low and therefore omitted from the equation. Retained energy (RE) was calculated as $\mathrm{ME}$ minus $\mathrm{HE}$. The non-protein respiratory quotient $\left(\mathrm{RQ}_{\mathrm{np}}\right)$ was calculated as $\mathrm{RQ}_{\mathrm{np}}=\left(\mathrm{CO}_{2}, \mathrm{~L}-[\mathrm{UN}, \mathrm{g} \times 6.25 \times\right.$ $0.774]) /\left(\mathrm{O}_{2}, \mathrm{~L}-[\mathrm{UN}, \mathrm{g} \times 6.25 \times 0.957]\right)$. Furthermore, the maximum protein retention was calculated according to a second order equation as described, and under the same assumptions, as given by Chwalibog et al. (1996) and Tauson et al. (1998).

\section{Statistical analyses}

Statistical analyses of data from the balance and respiration experiments were carried out by means of the MIXED Procedure in Statistical Analysis Systems Institute (SAS) (Littell et al., 1996) using the following model:

$$
Y_{\mathrm{ijkl}}=\mu+\alpha_{\mathrm{i}}+\beta_{\mathrm{j}}+(\alpha \beta)_{\mathrm{ij}}+\gamma_{\mathrm{k}}+\varepsilon_{\mathrm{ijkl}}
$$

where $Y_{\mathrm{ijkl}}$ is the $Y_{\mathrm{ijk}} \mathrm{t}$ th observation, $\mu$ is the general mean, $\alpha_{\mathrm{i}}$ is the fixed effect of diet (BP0, BP5, BP10 and BP15), $\beta_{\mathrm{j}}$ is the fixed effect of balance period (1 to 4$), \alpha \beta_{\mathrm{ij}}$ is the interaction between diet and balance period, $\gamma_{\mathrm{k}}$ is the fixed effect of block ( $\mathrm{A}$ and $\mathrm{B}$ ) and $\varepsilon_{\mathrm{ijk}}$ is the residual error. Data were analysed as repeated measurements and the heterogeneous autoregressive order 1 (ARH(1)) covariance structure was fitted (Littell et al., 1996). Results are presented as least squares means (LSmeans) and the square root of residuals (RR) is given for each variable. Pair-wise comparisons of LSmeans were made using the PDIFF option, and effects were considered significant if $P<0.05$. One observation from period 2 was omitted because of an injury not related to the dietary treatment. Another three observations (regarding one pig in period 2 and two pigs in period 3) were omitted from the analysis of the respiration data 
because of technical problems. A linear regression analysis of the percent of $\mathrm{N}$ derived from BPM and apparent digestibility of N was performed using PROC REG in SAS (1990).

\section{Results}

From period 2 and onwards all pigs performed well. After arrival, piglets in block A suffered from diarrhoea and pneumonia. The sick piglets were treated with antibiotics and no health problems were observed during the first balance period. During the interval between the first and the second periods, one pig in block $A$ and one spare pig died and the post mortem examination showed that death was caused by oedema disease. Another pig with clinical signs of the disease was treated with antibiotics and the remaining pigs were given a prophylactic vaccination (Danish Institute for Food and Veterinary Research, Copenhagen, Denmark). The dead pig from block $A$ was replaced with a spare pig. All results regarding intake of nutrients, amino acids, protein and energy metabolism are presented in relation to metabolic body size $\left(\mathrm{kg}^{0.75}\right)$.

\section{Intake of nutrients, digestibility and performance}

Effect of diet. Intake of DM did not differ between diets $(P=0.38)$ and the intake was measured to $93 \mathrm{~g} / \mathrm{kg}^{0.75}$ on diets BPO and BP10 and $97 \mathrm{~g} / \mathrm{kg}^{0.75}$ on BP5 and BP15. The intake of fat increased significantly $(P<0.001)$ with increasing dietary BPM (Table 2), because the content of fat in both the starter and growing-finishing diets increased with increasing BPM content (Table 1). The intake of lysine was significantly higher $(P<0.001)$ on diets BP0 and BP5 than on BP10 and BP15. The intake of methionine plus cysteine $(P=0.07)$ was the same on all diets.

The apparent digestibility of $N$ was lower $(P<0.01)$ on diets BP10 and BP15 than on BP0. The apparent digestibility of fat increased significantly $(P<0.001)$ with increasing dietary BPM, whereas the apparent digestibility of energy $(P=0.11)$ was unaffected by diet (Table 2$)$.

The daily gain during the balance periods was similar among groups, however numerically lowest on BP10 (688 g) and highest on BPO $(852 \mathrm{~g})$. The feed conversion rate $(P=0.12)$ did not differ between diets but there was a slight decrease with increasing dietary BPM (Table 2).

Effect of period. Intake of $\mathrm{DM}, \mathrm{CP}$, fat, carbohydrate and gross energy (all $P<0.001$ ) increased from period 1 to period 3 , but in period 4 the intake of nutrients was intermediate to the levels in periods 1 and 2 (Table 2).

The apparent digestibility of $\mathrm{N}$ was the same in periods 1 through 3 , whereas it was significantly higher in period 4 . The apparent digestibility of fat was highest in period 2 and lowest in period 1. The apparent digestibility of energy was lowest in period 3.

Table 2 Intake of nutrients and amino acids, digestibility of nutrients and performance in pigs fed increasing levels of bacterial protein meal (BPM) from weaning to a weight of approximately $80 \mathrm{~kg}$

\begin{tabular}{|c|c|c|c|c|c|c|c|c|c|c|c|c|c|}
\hline \multirow[b]{3}{*}{ No. of pigs } & \multicolumn{4}{|c|}{ Diet } & \multicolumn{4}{|c|}{ Period } & \multirow[b]{3}{*}{$\mathrm{RR}^{\dagger}$} & \multicolumn{4}{|c|}{ Significance } \\
\hline & BPO & BP5 & BP10 & BP15 & 1 & 2 & 3 & 4 & & Diet & Period & $D \times P$ & Block \\
\hline & 15 & 16 & 16 & 16 & 16 & 15 & 16 & 16 & & (D) & $(\mathrm{P})$ & & \\
\hline \multicolumn{14}{|l|}{ Intake of nutrients } \\
\hline Dry matter ( $\mathrm{g} / \mathrm{kg}^{0.75}$ per day) & 93 & 97 & 93 & 97 & $67^{\mathrm{D}}$ & $107^{\mathrm{B}}$ & $118^{\mathrm{A}}$ & $88^{C}$ & 0.95 & & $* * *$ & & *** \\
\hline $\begin{array}{l}\text { Protein }(\mathrm{N} \times 6.25) \\
\left(\mathrm{g} / \mathrm{kg}^{0.75} \text { per day }\right)\end{array}$ & 20 & 21 & 20 & 21 & $15^{\mathrm{D}}$ & $24^{\mathrm{B}}$ & $25^{\mathrm{A}}$ & $19^{C}$ & 0.87 & & $* * *$ & $\ddagger$ & $* * *$ \\
\hline Fat ( $\mathrm{g} / \mathrm{kg}^{0.75}$ per day) & $3.2^{\mathrm{d}}$ & $3.9^{c}$ & $4.7^{\mathrm{b}}$ & $6.1^{\mathrm{a}}$ & $3.7^{C}$ & $6.0^{B}$ & $4.7^{\mathrm{A}}$ & $3.5^{C}$ & 0.15 & $* * *$ & $* * *$ & $* * *$ & $* * *$ \\
\hline Carbohydrate ( $\mathrm{g} / \mathrm{kg}^{0.75}$ per day) & 63 & 66 & 62 & 64 & $44^{\mathrm{D}}$ & $71^{\mathrm{B}}$ & $80^{\mathrm{A}}$ & $60^{c}$ & 0.95 & & $* * *$ & & $* * *$ \\
\hline Gross energy (MJ $/ \mathrm{kg}^{0.75}$ per day) & 1.72 & 1.81 & 1.75 & 1.84 & $1.28^{\mathrm{D}}$ & $2.06^{\mathrm{B}}$ & $2.17^{\mathrm{A}}$ & $1.62^{C}$ & 0.07 & & $* * *$ & & $* * *$ \\
\hline Lysine $\left(\mathrm{g} / \mathrm{kg}^{0.75}\right.$ per day) & $1.1^{\mathrm{a}}$ & $1.1^{\mathrm{a}}$ & $1.0^{b}$ & $0.9^{b}$ & $0.7^{C}$ & $1.2^{\mathrm{A}}$ & $1.2^{\mathrm{A}}$ & $0.9^{B}$ & 0.04 & $* * *$ & $* * *$ & $\ddagger$ & $* * *$ \\
\hline $\begin{array}{l}\text { Methionine plus cysteine } \\
\left(\mathrm{g} / \mathrm{kg}^{0.75} \text { per day) }\right.\end{array}$ & 0.6 & 0.7 & 0.6 & 0.7 & $0.5^{\mathrm{D}}$ & $0.7^{B}$ & $0.8^{\mathrm{A}}$ & $0.6^{C}$ & 0.04 & $\neq$ & $* * *$ & $\neq$ & $* * *$ \\
\hline Threonine ( $\mathrm{g} / \mathrm{kg}^{0.75}$ per day) & 0.7 & 0.8 & 0.7 & 0.7 & $0.5^{\mathrm{D}}$ & $0.8^{B}$ & $0.9^{\mathrm{A}}$ & $0.7^{c}$ & 0.02 & $\neq$ & $* * *$ & * & $* * *$ \\
\hline Tryptophan ( $/ \mathrm{kg}^{0.75}$ per day) & $0.27^{\mathrm{c}}$ & $0.31^{b}$ & $0.31^{\mathrm{b}}$ & $0.35^{\mathrm{a}}$ & $0.21^{\mathrm{D}}$ & $0.35^{\mathrm{B}}$ & $0.39^{\mathrm{A}}$ & $0.29^{C}$ & 0.01 & $* * *$ & $* * *$ & $\ddagger$ & $* * *$ \\
\hline \multicolumn{14}{|l|}{ Apparent digestibility } \\
\hline Nitrogen & $0.78^{\mathrm{a}}$ & $0.77^{\mathrm{ab}}$ & $0.75^{\mathrm{c}}$ & $0.76^{b c}$ & $0.76^{\mathrm{B}}$ & $0.75^{\mathrm{B}}$ & $0.75^{\mathrm{B}}$ & $0.79^{\mathrm{A}}$ & 0.02 & $* *$ & $* * *$ & & \\
\hline Fat & $0.66^{\mathrm{c}}$ & $0.74^{\mathrm{b}}$ & $0.76^{\mathrm{b}}$ & $0.81^{\mathrm{a}}$ & $0.71^{C}$ & $0.77^{\mathrm{A}}$ & $0.74^{\mathrm{BC}}$ & $0.75^{\mathrm{B}}$ & 0.001 & $* * *$ & $* * *$ & $\neq$ & \\
\hline Energy & 0.82 & 0.82 & 0.81 & 0.81 & $0.82^{\mathrm{A}}$ & $0.82^{\mathrm{A}}$ & $0.80^{\mathrm{B}}$ & $0.82^{\mathrm{A}}$ & 0.01 & & $* * *$ & & \\
\hline \multicolumn{14}{|l|}{ Animal performance } \\
\hline Live weight $(\mathrm{kg})$ & 38.1 & 40.2 & 40.4 & 39.7 & $10.1^{\mathrm{D}}$ & $21.7^{C}$ & $47.5^{\mathrm{B}}$ & $79.1^{\mathrm{A}}$ & 0.43 & & $* * *$ & & $* * *$ \\
\hline Daily gain (g/day) & 852 & 806 & 688 & 772 & $322^{\mathrm{C}}$ & $596^{\mathrm{B}}$ & $1150^{\mathrm{A}}$ & $1050^{A}$ & 1.00 & & *** & & ** \\
\hline $\begin{array}{l}\text { Feed conversion rate } \\
\text { ( } \mathrm{kg} \text { feed } / \mathrm{kg} \text { gain) }\end{array}$ & 1.8 & 1.9 & 1.9 & 2.1 & $1.4^{\mathrm{B}}$ & $2.0^{\mathrm{A}}$ & $2.0^{\mathrm{A}}$ & $2.1^{\mathrm{A}}$ & 0.25 & & $* * *$ & * & \\
\hline
\end{tabular}

\footnotetext{
$a, b, c$ Values with different superscripts differ significantly, effect of diet $(P<0.05)$.

$A, B, C, D$ Values with different superscripts differ significantly, effect of period $(P<0.05)$.

${ }^{\dagger}$ Residual error.

${ }^{\ddagger}$ Approaching significance $(P<0.10)$.
} 
The pigs weighed approximately 10, 22, 48 and $79 \mathrm{~kg}$ at the midpoint of each balance period. The body weight gain was lowest in the first period and then increased significantly until balance period $3(P<0.001)$, after which the level remained the same in period 4 . The feed conversion was most efficient $(P<0.001)$ in the first period and then declined to a constant level for the rest of the experiment (Table 2).

Interaction between diet and period. There was a significant interaction effect between diet and period for the intake of fat $(P<0.001)$. For all diets the intake of fat increased with increasing dietary content of BPM but feed intake only increased from period 1 to 2 and then declined (Figure 1a).

\section{Nitrogen metabolism}

Effect of diet. Because of the lower DM intake, IN was slightly lower $\left(3.2 \mathrm{~g} / \mathrm{kg}^{0.75}\right)$ on diets BPO and BP10 than on BP5 and BP15 $\left(3.4 \mathrm{~g} / \mathrm{kg}^{0.75}\right)(P=0.15)$. The intake of nucleic acid nitrogen (NAN) increased with increasing dietary BPM. Due to the lower IN and apparent digestibility of $\mathrm{N}$, the amount of digested nitrogen (DN) was significantly lower on BP10 than on BP5. The faecal excretion of $N$ increased slightly $(P=0.12)$ with increasing dietary BPM. The excretion of $\mathrm{N}$ in urine ranged from 0.99 (BP0) to
$1.06 \mathrm{~g} / \mathrm{kg}^{0.75}$ (BP5 and BP15) $(P=0.44)$. There was a tendency $(P=0.08)$ for diet effect on $R N$, which was lowest on BP10 $\left(1.33 \mathrm{~g} / \mathrm{kg}^{0.75}\right)$ and highest on BP5 $\left(1.53 \mathrm{~g} / \mathrm{kg}^{0.75}\right)$. The utilisation of digested $\mathrm{N}$ for retention (RN/DN) ranged from $60 \%$ and $55 \% \quad(P=0.15)$. The partitioning of excreted $\mathrm{N}$ between faeces and urine was similar on all diets $(P=0.90)$ (Table 3$)$.

Effect of period. Both IN and DN increased significantly until period 3, after which they decreased significantly in period 4. UN excretion was higher $(P<0.001)$ in periods 3 and 4 than in periods 1 and 2 . $N$ retention was higher $(P<0.001)$ in periods 2 and 3 than in periods 1 and 4 . Utilisation of DN for retention (RN/DN) was most efficient in period $2(64 \%)$, after which it declined significantly to below $50 \%$ in period $4(P<0.001)$. This decline was reflected in the partitioning of $\mathrm{N}$ excretion between faeces and urine $(P<0.001)$, the latter increasing continuously from period 2 to period 4 (Table 3).

Interaction between diet and period. Interaction effects were observed for the utilisation of DN for retention (RN/DN), excretion of UN and the total excretion of $\mathrm{N}$ $(P<0.001)$ (Figure $1 \mathrm{~b}$ to $\mathrm{d})$. The utilisation of $\mathrm{DN}$ for retention was lower on BP10 and BP15 than on BP0 and BP5 in periods and 1 and 2 whereas it was the same or better in periods 3 and 4 . The excretion of UN increased
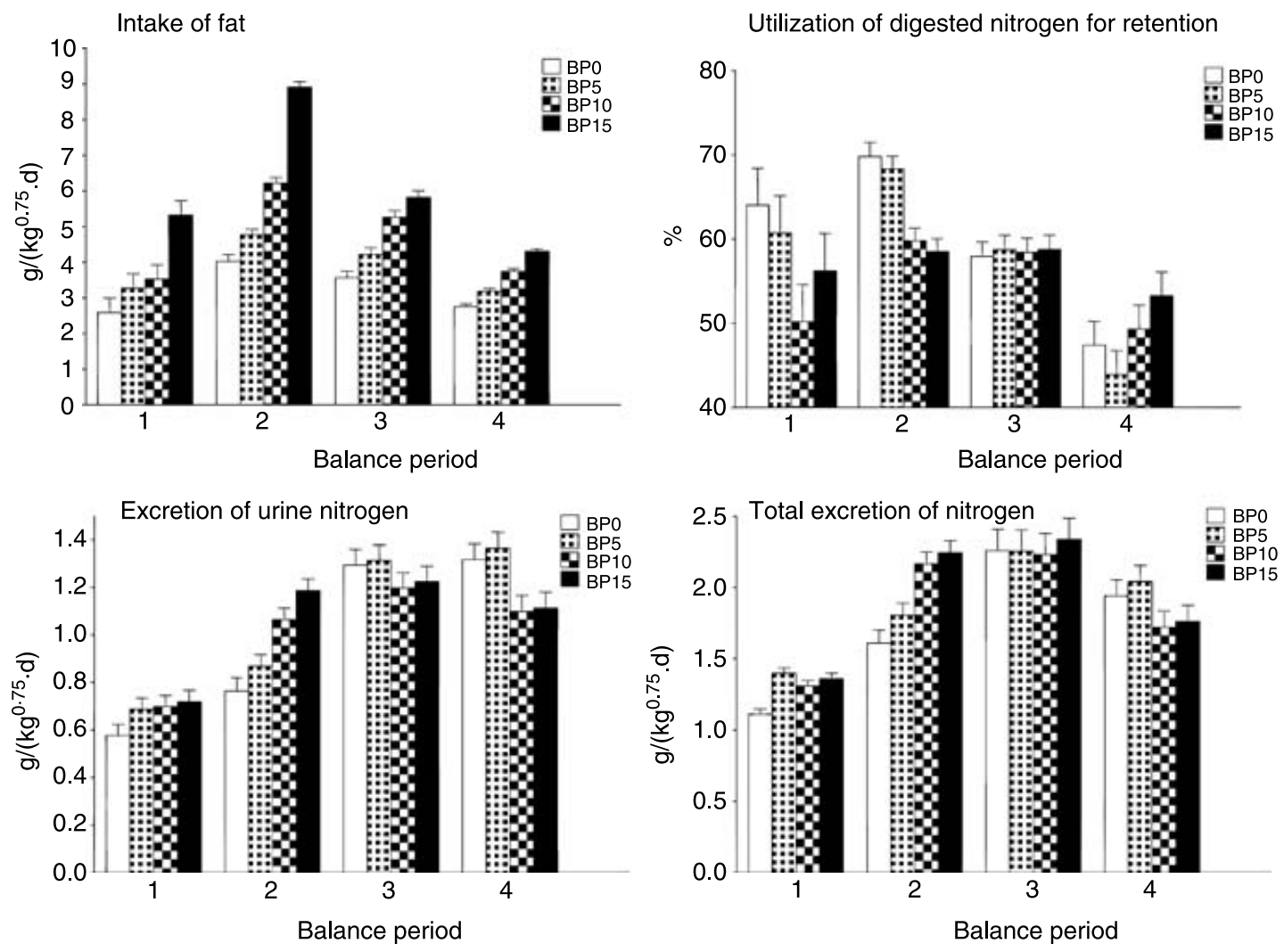

Figure 1 (a) Intake of fat, (b) utilisation of digested nitrogen for retention, (c) excretion of urinary nitrogen, and (d) total excretion of nitrogen for each balance period and diet for pigs fed increasing levels of dietary bacterial protein meal. The pigs weighed about 10.1, 21.7, 47.5, and 79.1 kg in the first, second, third, and fourth balance periods, respectively. 
Bacterial protein meal in diets for growing pigs

Table 3 Protein metabolism in pigs fed increasing levels of bacterial protein meal (BPM) from weaning to a weight of approximately $80 \mathrm{~kg}^{\dagger}$

\begin{tabular}{|c|c|c|c|c|c|c|c|c|c|c|c|c|c|}
\hline \multirow[b]{3}{*}{ No. of pigs } & \multicolumn{4}{|c|}{ Diet } & \multicolumn{4}{|c|}{ Period } & \multirow[b]{3}{*}{$\mathrm{RR}$} & \multicolumn{4}{|c|}{ Significance } \\
\hline & BP0 & BP5 & BP10 & BP15 & 1 & 2 & 3 & 4 & & & & & \\
\hline & 15 & 16 & 16 & 16 & 16 & 15 & 16 & 16 & & Diet (D) & Period (P) & $D \times P$ & Block \\
\hline IN (g/kg ${ }^{0.75}$ per day) & 3.21 & 3.40 & 3.18 & 3.38 & $2.33^{\mathrm{D}}$ & $3.76^{\mathrm{B}}$ & $4.07^{\mathrm{A}}$ & $3.03^{C}$ & 0.14 & & $* * *$ & $\neq$ & $* * *$ \\
\hline IN-NAN (g/kg ${ }^{0.75}$ per day) & 3.13 & 3.22 & 2.95 & 3.06 & $2.19^{\mathrm{D}}$ & $3.52^{\mathrm{B}}$ & $3.80^{\mathrm{A}}$ & $2.84^{C}$ & 0.13 & $\neq$ & $* * *$ & $\neq$ & $* * *$ \\
\hline DN (g/kg ${ }^{0.75}$ per day) & $2.51^{\mathrm{ab}}$ & $2.62^{a}$ & $2.37^{\mathrm{b}}$ & $2.55^{\mathrm{ab}}$ & $1.78^{\mathrm{D}}$ & $2.82^{\mathrm{B}}$ & $3.07^{\mathrm{A}}$ & $2.39^{C}$ & 0.13 & * & $* * *$ & & $* * *$ \\
\hline FN (g/kg ${ }^{0.75}$ per day) & 0.73 & 0.82 & 0.84 & 0.86 & $0.62^{\mathrm{B}}$ & $0.98^{\mathrm{A}}$ & $1.01^{\mathrm{A}}$ & $0.64^{\mathrm{B}}$ & 0.002 & & $* * *$ & & \\
\hline UN ( $\mathrm{g} / \mathrm{kg}^{0.75}$ per day) & 0.99 & 1.06 & 1.01 & 1.06 & $0.67^{C}$ & $0.97^{B}$ & $1.26^{\mathrm{A}}$ & $1.22^{\mathrm{A}}$ & 0.09 & & $* * *$ & $* * *$ & \\
\hline RN ( $\mathrm{g} / \mathrm{kg}^{0.75}$ per day) & 1.50 & 1.53 & 1.33 & 1.46 & $1.04^{\mathrm{B}}$ & $1.81^{\mathrm{A}}$ & $1.80^{\mathrm{A}}$ & $1.16^{\mathrm{B}}$ & 0.13 & $\neq$ & $* * *$ & & $* * *$ \\
\hline RN/DN (\%) & 59.8 & 58.0 & 54.4 & 56.7 & $57.8^{\mathrm{B}}$ & $64.1^{\mathrm{A}}$ & $58.5^{\mathrm{B}}$ & $48.5^{C}$ & 0.94 & & $* * *$ & $* * *$ & $* *$ \\
\hline $\mathrm{N}$ excretion & 1.73 & 1.87 & 1.86 & 1.92 & $1.29^{C}$ & $1.95^{\mathrm{B}}$ & $2.27^{\mathrm{A}}$ & $1.87^{\mathrm{B}}$ & 0.08 & & $* * *$ & $* * *$ & $* * *$ \\
\hline - in faeces (\%) & 43 & 44 & 45 & 45 & $48^{A B}$ & $50^{\mathrm{A}}$ & $44^{\mathrm{B}}$ & $35^{C}$ & 0.87 & & $* * *$ & $\neq$ & $* *$ \\
\hline - in urine $(\%)$ & 57 & 56 & 55 & 55 & $52^{\mathrm{BC}}$ & $50^{C}$ & $56^{\mathrm{B}}$ & $65^{A}$ & 0.87 & & $* * *$ & $\neq$ & ** \\
\hline
\end{tabular}

a,b Values with different superscripts differ significantly, effect of diet $(P<0.05)$.

$A, B, C, D$ Values with different superscripts differ significantly, effect of period $(P<0.05)$.

${ }^{\dagger}$ Abbreviations are: $I N=$ ingested nitrogen, IN-NAN = ingested nitrogen minus nucleic acid nitrogen, $D N=$ apparently digested nitrogen, $U N=$ urinary nitrogen, $\mathrm{FN}=$ faecal nitrogen, $\mathrm{RN}=$ retained nitrogen, $\mathrm{RR}=$ residual error.

${ }^{\ddagger}$ Approaching significance $(P<0.10)$.

with increasing dietary level of BPM in periods 1 and 2 whereas it was lower on BP10 and BP15 than on BP0 and BP5 in periods 3 and 4 . The ranking of the different diets for the excretion of total $\mathrm{N}$ differed in the different periods and no clear pattern could be discerned.

\section{Energy metabolism}

Effect of diet. Intake of ME $(P=0.22), \mathrm{HE}(P=0.29)$ and RE $(P=0.25)$ were not affected by diet. Heat production was highest on BP15 but did not differ significantly from the levels on the other diets. RE was not significantly affected by diet. Partitioning of $\operatorname{RE}(P=0.07)$ between protein and fat $(P=0.33)$ was not affected by diet. The non-protein respiration quotient was not affected by diet $(P=0.16)$.

Effect of period. The intake of ME was higher $(P<0.001)$ in periods 2 and 3 than in periods 1 and 4 . This pattern was partly reflected in $\mathrm{HE}$, although the lowest $\mathrm{HE}$ values were recorded in period 4 . Consequently, RE was low in period 1, increased by almost $0.5 \mathrm{MJ} / \mathrm{kg}^{0.75}$ in period 2 and remained at this level in period 3 . HE and RE values in the two last periods were probably somewhat affected by the decline in ME intake observed on the days of the respiration experiments $\left(4 \mathrm{gDM}\right.$ per kg $\mathrm{g}^{0.75}$ in period 3 and $27 \mathrm{gDM}$ per $\mathrm{kg}^{0.75}$ in period 4), resulting in RE values in period 4 being lower than expected from the measured body weight gain. The non-protein respiratory coefficient was lower in period 4 than in period 3 (Table 4).

\section{Discussion}

When performing an experiment from shortly after weaning until slaughter weight of the pigs, the problem of changing nutrient requirements over the experimental period complicates the diet formulation: if the same diet is used throughout the experiment pigs are inevitably either underfed or overfed during some part of the experiment. On the other hand, if two diets are used, pigs are fed closer to their requirements, but there might be some confounding between diets and periods. We chose the latter solution, because we wanted to feed the pigs as close to their requirements as possible and furthermore, this experiment was run in parallel to a production trial in which pigs were followed from weaning until a live weight of 105 to $110 \mathrm{~kg}$ (Øverland et al., 2004).

Intake of nutrients, performance and digestibility

The diets were generally readily consumed and the animals performed well even on the diet with highest inclusion level, where BPM supplied approximately $50 \%$ of dietary $\mathrm{N}$. Although our performance data, because of the small number of animals per treatment, only have indicative value, our results concur with those of Øverland et al. (2004): using the same diets as in the present study, they found no differences in feed intake but a small reduction in average daily gain on the diet containing the most BPM.

The amino acid composition differed somewhat between diets, the control diet (BPO) having an almost ideal pattern of essential amino acids (NRC, 1998), whereas increasing BPM inclusion resulted in gradually lower lysine content and higher methionine and tryptophan contents in the diet. The lysine contents of all starter diets, declining from $10.7 \mathrm{~g} / \mathrm{kg}$ feed on BPO to $8.6 \mathrm{~g} / \mathrm{kg}$ feed on BP15, were lower than recommended by NRC (1998) for pigs weighing 10 to $20 \mathrm{~kg}$. Thus the differences in lysine content may have caused low RN in the two first periods, the level decreasing with increasing dietary content of BPM. All the growing-finishing diets contained sufficient amounts of lysine, according to the NRC (1998) recommendations.

The apparent digestibility of $\mathrm{N}$ in BPM at the terminal ileum and of the total digestive tract of pigs has been estimated to be 0.78 and 0.85 , respectively, using BPM as the sole source of protein (Skrede et al., 1998). Regression 
Hellwing, Tauson, Kjos and Skrede

Table 4 Energy metabolism in pigs fed increasing levels of bacterial protein meal (BPM) from weaning to a weight of approximately $80 \mathrm{~kg}^{\dagger}$

\begin{tabular}{|c|c|c|c|c|c|c|c|c|c|c|c|c|}
\hline \multirow[b]{3}{*}{ No. of pigs } & \multicolumn{4}{|c|}{ Diet } & \multicolumn{4}{|c|}{ Period } & \multirow[b]{3}{*}{ RR } & \multicolumn{3}{|c|}{ Significance } \\
\hline & BPO & BP5 & BP10 & BP15 & 1 & 2 & 3 & 4 & & & & \\
\hline & 14 & 16 & 15 & 15 & 16 & 14 & 14 & 16 & & Diet (D) & Period $(P) \quad D \times P$ & Block \\
\hline ME ( $\left(\mathrm{kJ} / \mathrm{kg}^{0.75}\right.$ per day) & 1362 & 1426 & 1360 & 1442 & $1021^{C}$ & $1637^{\mathrm{B}}$ & $1677^{B}$ & $1255^{C}$ & 0.89 & & $* * *$ & $* * *$ \\
\hline HE (kJ/kg ${ }^{0.75}$ per day) & 741 & 730 & 749 & 777 & $678^{c}$ & $821^{\mathrm{B}}$ & $869^{A}$ & $629^{D}$ & 0.98 & & $* * *$ & *** \\
\hline $\mathrm{RE}\left(\mathrm{kJ} / \mathrm{kg}^{0.75}\right.$ per day) & 620 & 696 & 613 & 664 & $340^{C}$ & $819^{A}$ & $808^{A}$ & $625^{B}$ & 0.85 & & $* * *$ & $* *$ \\
\hline $\mathrm{RPE}\left(\mathrm{kJ} / \mathrm{kg}^{0.75}\right.$ per day) & 220 & 226 & 195 & 217 & $154^{\mathrm{B}}$ & $265^{A}$ & $267^{\mathrm{A}}$ & $172^{\mathrm{B}}$ & 0.97 & $\neq$ & $* * *$ & $* * *$ \\
\hline $\mathrm{RFE}\left(\mathrm{kJ} / \mathrm{kg}^{0.75}\right.$ per day) & 400 & 470 & 419 & 446 & $185^{C}$ & $554^{\mathrm{A}}$ & $543^{\mathrm{A}}$ & $454^{\mathrm{B}}$ & 0.90 & & $* * *$ & \\
\hline $\mathrm{RQ}_{\mathrm{NP}}$ & 1.07 & 1.06 & 1.04 & 1.05 & $0.97^{C}$ & $1.08^{\mathrm{B}}$ & $1.12^{\mathrm{A}}$ & $1.05^{\mathrm{B}}$ & 0.04 & & $* * *$ & \\
\hline
\end{tabular}

$\mathrm{A}, \mathrm{B}, \mathrm{C}, \mathrm{D}$ Values with different superscripts differ significantly, effect of period $(P<0.05)$.

${ }^{\dagger}$ Abbreviations are: $\mathrm{ME}=$ metabolizable energy, $\mathrm{HE}=$ heat production, $\mathrm{RE}=$ retained energy, $\mathrm{RPE}=$ energy retained in protein, $\mathrm{RFE}=$ energy retained in fat, $\mathrm{RQ}_{\mathrm{np}}=\mathrm{N}$-free respiratory quotient, $\mathrm{RR}=$ residual error.

${ }^{\ddagger}$ Approaching significance $(P<0.10)$.

analysis of our data indicated a lower digestibility, although the equation had a low $R^{2}$. However, the apparent digestibility of $\mathrm{N}$ of the control diet based on SBM was also low, and the effects of replacing SBM with BPM were minor.

The explanation for the slightly lower apparent N digestibility with increasing inclusion of BPM in the diet may be that the cell wall of the bacteria either had a low digestibility, or even was indigestible. However, Soeder (1977) stated that a completely indigestible cell wall would only cause a minor decline in $\mathrm{N}$ digestibility. The explanation as to why the present study found that BPM consumption resulted in slightly lower apparent digestibility of $\mathrm{N}$ than those resulting from SBM consumption may be that $M$. capsulatus, in addition to the cell walls, contains a complex system of poorly digestible internal membranes. This is in accordance with a higher $\mathrm{N}$ digestibility in a membrane-reduced extract of autolysed BPM than the crude autolysed BPM (Schøyen et al., 2005).

The increasing apparent digestibility of fat with increasing dietary levels of BPM found in our study was likely due to the increasing fat content of the diets, and hence reduced contribution to faecal fat from endogenous losses (Jørgensen et al., 1992 and 1993). An estimate of the true fat digestibility, assuming an endogenous loss of $4.4 \mathrm{~g} / \mathrm{kg}$ DM (Jørgensen et al., 1993), indicated a higher true fat digestibility in BPM than in the fat sources of the control diet.

\section{Protein metabolism}

Our diets were designed to be iso-nitrogenous, and protein metabolism traits were generally found to be independent of the inclusion level of BPM in the diet. The exception was the low apparent digestibility of $\mathrm{N}$ and DN on diet BP10, which was at least partly caused by a low DM intake. Despite less protein being available for retention and the lysine content in the diets being slightly below the NRC (1998) recommendations, the RN on BP15 was only slightly and non-significantly lower than the highest value, which was found on diet BP5. This result concurs with our findings in mink, where RN was unaffected by dietary BPM level (Hellwing et al., 2005). In slaughter chickens, Hellwing et al. (2006) also found similar RN levels for all BPMcontaining diets.

The utilisation of $\mathrm{DN}$ for $\mathrm{N}$ retention was numerically higher on diet BP0 than on BP10, but the $\mathrm{N}$ derived from nucleic acids increased from $2.5 \%$ on BP0 to approximately $10 \%$ on BP15 and this fraction cannot be directly used for protein synthesis. The fate of nucleic acid $\mathrm{N}$ is important in relation to protein metabolism. Pig experiments have shown that up to $40 \%$ of adenine, $15 \%$ of guanine and $20 \%$ of the pyrimidine bases in the diet were retained in the body (Greife and Molnar, 1984a and b). From studies by Roth and Kirchgessner (1978) and Greife and Molnar (1984a) it has been indicated that $\mathrm{NH}_{3}$ from the decomposition of purine and pyrimidine bases can be used for synthesis of non-essential amino acids and/or incorporated directly in the body, which might be an explanation for the unchanged RN in BPM diets compared with the control diet. Furthermore, it was shown that the excretion of purine base derivatives in urine in pigs on BP5, BP10 and BP15 were lower than the intake (Hellwing et al., 2007). Collectively, our data did not support the hypothesis that increasing dietary supply of BPM would have a negative effect on protein retention.

The total retention of protein ( $\mathrm{g}$ per pig and day) in different balance periods was in good agreement with results obtained by Whittemore et al. (1988), although the highest retention we found was in balance period 3 at an average pig live weight of $48 \mathrm{~kg}$, while Whittemore et al. (1988) recorded maximum protein retention at $75 \mathrm{~kg}$ live weight. To achieve maximum protein retention the supply of both digestible protein and ME must be sufficient. The criteria for this (DN $>1.9 \mathrm{~g} / \mathrm{kg}^{0.75}$.per day, ME $>1100$ $\mathrm{kJ} / \mathrm{kg}^{0.75}$.per day; Chwalibog et al., 1996; Tauson et al., 1998) were fulfilled in this study. The pattern of protein retention can be modelled according to a second order function. Data pertaining to pigs of mixed sexes from 2 to $120 \mathrm{~kg}$ (Chwalibog et al., 1996) or intact boars (Tauson et al., 1998) gave peak values of $180 \mathrm{~g} /$ day at $98 \mathrm{~kg}$ and $227 \mathrm{~g} /$ day at $135 \mathrm{~kg}$, respectively. Using a similar approach with the present material gave a peak value of $210 \mathrm{~g} /$ day 
at $62 \mathrm{~kg}$, but the equation had a significant negative intercept, so the result has only indicative value. Considering the effects of sex, our estimated maximum protein retention level seems reasonable, even though it was achieved at a lower than expected live weight.

\section{Energy metabolism}

Increasing inclusion of BPM in the diet did not affect HE in growing pigs, which is in agreement with the results of previous studies on mink (Hellwing et al., 2005) and slaughter chickens (Hellwing et al., 2006). This means that even if assuming $100 \%$ digestion of the purine and pyrimidine bases, the energy cost for the excretion of their metabolites would be small in relation to other metabolic processes. Therefore, the hypothesis that increasing dietary supply of BPM would have a negative impact on energy retention, was not supported by our results.

Until period 3, HE increased linearly in relation to the metabolic body size of the pigs, as also shown by Thorbek (1975). In period 4, however, the lowest HE values were recorded, and $R Q_{n p}$ was found to be lower than in periods 2 and 3, which was caused by a lower feed intake during the respiration experiments. During the last period the pigs were observed to spend most of the time sleeping. The feed intake during the complete balance period did not differ between diets, so comparisons between diets are still valid, whereas comparisons to other balance periods should be made with caution.

\section{Conclusion}

The present data suggest that inclusion of BPM up to $50 \%$ of dietary $\mathrm{N}$ in the diets of growing pigs does not affect protein and energy metabolism. With increasing dietary levels of BPM, the amount of ingested amino acid $\mathrm{N}$ decreased, but the animals were still able to maintain protein retention at the same level. This indicated a slightly more efficient utilisation of dietary amino acid $\mathrm{N}$. The hypothesis that increased intake of $\mathrm{N}$ from RNA and DNA with increasing dietary levels of BPM would result in decreased retention of protein and energy was therefore rejected.

\section{Acknowledgements}

This experiment was part of the strategic research programme, 'Protein produced from natural gas: a new feed resource for fish and domestic animals'. We gratefully acknowledge the financial support of the Research Council of Norway (grant no. 143196/140) for this programme. Skilful technical assistance with the chemical analyses was provided by Merethe Stubgaard, Lotte Ørbæk and Anna Rasmussen and with the operation of the respiration unit by Abdalla Ali, assistance for which the authors wish to express their sincere gratitude.

\section{References}

Bech-Andersen S 1991. Determination of tryptophan with HPLC after alkalinehydrolysis in autoclave using alpha-methyl-tryptophan as internal standard. Acta Agriculturae Scandinavica 41, 305-309.
Braude R, Hosking ZD, Mitchell KG, Plonka S and Sambrook E 1977. Pruteen, a new source of protein for growing pigs. I. Metabolic experiment: utilization of nitrogen. Livestock Production Science 4, 79-89.

Brouwer E 1965. Report of sub-committee on constants and factors. In Energy metabolism. In European Association for Animal Production publication no. 11, (ed KL Blaxter), pp. 441-443. Academic Press, London.

Chwalibog A, Jakobsen K and Thorbek G 1996. The pattern of protein retention in pigs from 2 to $120 \mathrm{~kg}$ live weight. Archives of Animal Nutrition 49, 181-186.

Chwalibog A, Tauson A-H and Thorbek G 2004. Energy metabolism and substrate oxidation in pigs during feeding, starvation and re-feeding. Journal of Animal Physiology and Animal Nutrition 88, 101-112.

European Community 1998. Commission directive 98/64/EEC. Official Journal of the European Communities L257, 4-28.

Greife HA 1984. Die Nukleinsäuren - ein gesundheitlicher Risikofaktor beim Einsatz von "Single-Cell Protein" in der Tierernährung? (Teil 1). Kraftfutter 67, 412-414.

Greife HA and Molnar S 1984a. ${ }^{14} \mathrm{C}$-Tracerstudien zum Nukleinsäuren-Stoffwechsel von Jungratte, Küken und Ferkeln. 5. Mitteillung: Untersuchungen zum Purinstoffwechsel des Kükens. eitschrift für Tierphysiologie, Tierernährung und Futtermittelkunde 51, 31-39.

Greife HA and Molnar S 1984b. ${ }^{14} \mathrm{C}$-Tracerstudien zum Nukleinsäuren-Stoffwechsel von Jungratten, Küken un Ferkeln. 6. Mitteilung: Untersuchungen zum Pyrimidinstoffwechsel des Kükens. Zeitschrift für Tierphysiologie, Tierernährung und Futtermittelkunde 51, 39-51.

Hellwing ALF, Tauson A-H, Ahlstrøm $\varnothing$ and Skrede A 2005. Nitrogen and energy balance in growing mink (Mustela vison) fed different levels of bacterial protein meal produced with natural gas. Archives of Animal Nutrition 59, 335-352.

Hellwing ALF, Tauson A-H, and Skrede, A 2006. Effect of bacterial protein meal on protein and energy metabolism in growing chickens. Archives of Animal Nutrition 60, 365-381.

Hellwing, ALF, Tauson, A-H, Skrede, A, Kjos, NP and Ahlstrøm Ø 2007. Bacterial protein meal in diets for pigs and mink - protein turnover and urinary excretion of purine base derivates. Archives of Animal Nutrition, in press.

Herbel W and Montag A 1987. Nucleo-compounds in protein-rich food. Zeitschrift für Lebensmittel Untersuchung und Forschung 185, 119-122.

Imafidon GI and Sosulski FW 1990. Nucleic acid nitrogen of animal and plant foods. Journal of Agricultural and Food Chemistry 38, 118-120.

Jørgensen $\mathrm{H}$, Jakobsen $\mathrm{K}$ and Eggum BO 1992. The influence of different protein, fat and mineral levels on the digestibility of fat and fatty-acids measured at the terminal ileum and in feces of growing pigs. Acta Agriculturae Scandinavica Section A - Animal Science 42, 177-184.

Jørgensen $H$, Jakobsen $K$ and Eggum BO 1993. Determination of endogenous fat and fatty-acids at the terminal ileum and on feces in growing pigs. Acta Agriculturae Scandinavica Section A - Animal Science 43, 101-106.

Kiessling A and Askbrandt S 1993. Nutritive-value of two bacterial strains of single-cell protein for rainbow trout (Oncorhynchus mykiss). Aquaculture 109, 119-130.

Lassek E and Montag A 1990. Nucleostoffe in kohlenhydratreichen Lebensmitteln. Zeitschrift für Lebensmittel Untersuchung und Forschung 190, 17-21.

Littell RC, Milliken GA, Stroup WW and Wolfinger RD 1996. SAS ${ }^{\circledR}$ system for mixed models. SAS Institute Inc., Cary, NC.

National Research Council 1998. Nutrients requirements of swine, 10th reveised edition. National Academy Press, Washington, DC.

Norwegian Feed Table 2002. http://www.umb.no/iha/fortabell/index.php

Øverland M, Skrede A and Matre T 2001. Bacterial protein grown on natural gas as feed for pigs. Acta Agricultura Scandinavica, Section A, Animal Science 51, 97-106.

Øverland M, Kjos NP and Skrede A 2004. Effect of bacterial protein meal grown on natural gas on growth performance and carcass traits of pigs. Italian Journal of Animal Science 3, 323-336.

Roth FX and Kirchgessner M 1978. N-Verwertung alimentärer Ribonucleinsäure beim Ferkel. Zeitschrift für Lebensmittel Untersuchung und Forschung 40, 315-325.

Rumsey GL, Hughes SG, Smith RR, Kinsella JE and Shetty KJ 1991. Digestibility and energy values of intact, disrupted and extracts from brewers dried 
yeast fed to rainbow trout (Oncorhynchus mykiss). Animal Feed Science and Technology 33, 185-193.

Statistical Analysis Systems Institute 1990. SAS/STAT ${ }^{\circledR}$ user's guide, version 6, 4th edition. SAS institute Inc., Cary NC.

Schøyen HF, Frøyland JRK, Sahlstrøm S, Knutsen SH and Skrede A 2005. Effects of autolysis and hydrolysis of bacterial protein meal grown on natural gas on chemical characterization and amino acid digestibility. Aquaculture 248, 27-33.

Skrede A and Ahlstrøm $\varnothing$ 2002. Bacterial protein produced on natural gas: a new potential feed ingredient for dogs evaluated using the blue fox as a model. Journal of Nutrition 132, 1668S-1669S.

Skrede A, Berge GM, Storebakken T, Herstad O, Aarstad KG and Sundstøl F 1998. Digestibility of bacterial protein grown on natural gas in mink, pigs, chicken and Atlantic salmon. Animal Feed Science and Technology 76, 103-116.

Skrede A, Schøyen HF, Svihus B and Storebakken T 2003. The effect of bacterial protein grown on natural gas on growth performance and sensory quality of broiler chickens. Canadian Journal of Animal Science 83, 229-237.

Soeder CJ 1977. Biochemical aspects of single cell protein. In Biochemical aspects of new protein food (eds J Adler-Nissen, BO Eggum, L Munck and HS Olsen) FEBS Federation of European Biochemical Societies 11th Meeting
Copenhagen, volume 44, symposium A3, pp. 63-72. Pergamon Press Ltd, Oxford.

Storebakken T, Baeverfjord G, Skrede A, Olli JJ and Berge GM 2004. Bacterial protein grown on natural gas in diets for Atlantic salmon, Salmo salar, in freshwater. Aquaculture 241, 413-425.

Tauson A-H, Chwalibog A, Jakobsen K and Thorbek G 1998. Pattern of protein retention in growing boars of different breeds, and estimation of maximum protein retention. Archives of Animal Nutrition 51, 253-262.

Thorbek G 1975. Studies on energy metabolism in growing pigs. II. Protein and fat gain in growing pigs fed different feed compounds. Efficiency of utilization of metabolizable energy for growth. 424. Beretning fra Statens Husdyrsbrugsforsøg. Landhusholdningsselskabets forlag, Copenhagen, Denmark

Tiemeyer W, Erbersdobler H and Giesecke D 1981. Charakterisierung der Nucleinsäurefraktion und Aminosäurenmuster in einzeller-Proteinen als potentielle Nahrungsmittel. Zeitschrift für Lebensmittel Untersuchung und Forschung 173, 301-305.

Whittemore CT, Tullis JB and Emmans GC 1988. Protein growth in pigs. Animal Production 46, 437-445. 